\title{
The leaves of green plants as well as a cyanobacterium, a red alga, and fungi contain insulin-like antigens
}

\footnotetext{
L.B. Silva ${ }^{1}$, S.S.S. Santos ${ }^{1}$, C.R. Azevedo ${ }^{1}$, M.A.L. Cruz ${ }^{1}$, T.M. Venâncio ${ }^{1}$, C.P. Cavalcante' ${ }^{2}$ A.F. U chôa ${ }^{1}$, S. Astolfi Filho², A.E.A. Oliveira' K.V.S. Fernandes ${ }^{1}$ and J. Xavier-Filho ${ }^{1}$
}

\author{
'Laboratório de Q uímica e Função de Proteínas e Peptídeos, \\ Centro de Biociências e Biotecnologia, Universidade Estadual do Norte Fluminense, \\ Campos dos Goytacazes, RJ, Brasil \\ 2Laboratório de Tecnologia de DNA, Universidade Federal do Amazonas, \\ Manaus, AM, Brasil
}

\section{Correspondence \\ J. Xavier-Filho \\ Laboratório de Q uímica e Função de Proteínas e Peptídeos Centro de Biociências e Biotecnologia, UENF 28015-620 Campos dos Goytacazes, RJ Brasil \\ Fax: + 55-22-2726-1520 \\ E-mail: xavier@uenf.br \\ Research supported by CAPES, CNPq, PRONEX and FINEP and the Universidade Estadual do Norte Fluminense supporting body, FEN ORTE.}

Received December 6, 2001 Accepted January 31, 2002

\begin{abstract}
We report the detection of insulin-like antigens in a large range of species utilizing a modified ELISA plate assay and Western blotting. We tested the leaves or aerial parts of species of Rhodophyta (red alga), Bryophyta (mosses), Psilophyta (whisk ferns), Lycopodophyta (club mosses), Sphenopsida (horsetails), gymnosperms, and angiosperms, including monocots and dicots. We also studied species of fungi and a cyanobacterium, Spirulina maxima. The wide distribution of insulin-like antigens, which in some cases present the same electrophoretic mobility as bovine insulin, together with results recently published by us on the amino acid sequence of an insulin isolated from the seed coat of jack bean (Canavalia ensiformis) and from the developing fruits of cowpea (Vigna unguiculata), suggests that pathways depending on this hormone have been conserved through evolution.
\end{abstract}

\section{Introduction}

The peptide hormone insulin was discovered in 1921 by Banting and Best (1). Immediately after its discovery and isolation from dogs, two reports on the positive results obtained with similar purified preparations from several plants on the lowering of glucose levels in diabetic animals were published by Collip (2) and Best (3), investigators involved in the original discovery. One of them, (Collip) named the isolated protein "glucokinin" because he did not want to give the same name, insulin, to a protein originating from plants, which do not have a pancreas or islets. Although many reports on the beneficial effects of plant-derived materials on the alleviation of diabetes symptoms continued to appear (4) it was only in 1974 that further work on the possible presence of insulin in plants was published (5). Khanna et al. (5-7) reported on the isolation of a protein from the fruits of the bitter gourd (Momordica charantia) that exerted positive effects on diabetic patients and showed properties similar to insulin. Following these reports, Collier et al. (8) reported on the isolation from spinach, rye and Lemna gibba of proteins with 
molecular weights, chromatographic properties, immunological characteristics and biological activities identical to those of vertebrate insulins. No further structural information was given for these molecules at the time.

Insulin is part of the signaling pathways involved in the internalization of glucose into several types of vertebrate cells $(9,10)$. Other actions of insulin refer to its effects on protein synthesis and gene transcription (11). Besides pancreatic tissues in vertebrates, insulin has been detected in different tissues of members of several other phyla, suggesting that pathways in which it is involved have been evolutionarily conserved (12-15). In plants, apart from the many reports on the lowering of blood sugar levels in diabetic animals by extracts of plant parts $(4,16,17)$, no place for insulin as a member of signaling pathways has been suggested by researchers in the fields of glucose mobilization or transport (18-21). Nevertheless, it has been shown that added insulin increases germination of some seeds (22; Oliveira AEA and Xavier-Filho J, unpublished results), accelerates synthesis of ribosomal proteins in germinating maize embryos $(23,24)$, and increases the activity of glyoxysomal enzymes involved in the conversion of fat to carbohydrate in maize (22).

The objective of the present study was to show that insulin-like antigens are present in the leaves of a multiplicity of green plant species, a red alga, a cyanobacterium, and fungi. In many cases these insulin-like antigens show characteristic molecular weights of the vertebrate insulins.

\section{Material and Methods}

\section{Plant material}

Leaves of the plants (Table 1) utilized were collected at the Rio de Janeiro Botanical Garden, locally in Campos dos Goytacazes, Manaus (Amazon), or acquired commercially. Arabidopsis thaliana leaves were kindly provided by Larissa Nogueira S. Menezes from the Departamento de Genética, Universidade Federal do Rio de Janeiro. After collection, leaves were washed in tap water and dried at $40^{\circ} \mathrm{C}$ in a circulating air oven. After drying, leaves were powdered in a mortar and kept in sealed bottles for further protein extraction. The cyanobacterium Spirulina maxima was bought from Herbarium Laboratório Botânico Ltda., Curitiba, PR, Brazil. The red alga (Rhodophyta) Gracilariopsis sp was collected by André Touil of the Laboratório de Ciências Ambientais, CBB, Universidade Estadual do Norte Fluminense, Campos dos Goytacazes, in the Lagoa do Açu (Rio de Janeiro, RJ, Brazil). The yeast Saccharomyces cerevisiae and the fungus Shiitake (Lentinus edodes) were commercial products.

\section{Antibodies}

A highly purified antibody (Cat. No. GGG7303/971577) against human insulin raised in guinea pigs was purchased from Peninsula Laboratories (San Carlos, CA, USA). A peroxidase-conjugated guinea pig anti-IgG antibody (A5545) raised in goats was bought from Sigma (St. Louis, MO, USA).

\section{Protein extraction}

Protein in the finely powdered plant materials was extracted (1:10 ratio) with a solution of $4.0 \%$ SDS, $12 \%$ glycerol, $50 \mathrm{mM}$ Tris-HCl, 35 mM EDTA, pH 6.8, and 0.01\% bromophenol blue for $2 \mathrm{~h}$ at $4{ }^{\circ} \mathrm{C}$ with continuous shaking. The suspensions were centrifuged at $4,000 \mathrm{~g}$ and the supernatants utilized for polyacrylamide gel electrophoresis and Western blotting. The same buffer was utilized for insulin solubilization. To assess the presence of insulin-like antigens, the plant materials were extracted (1:10 ratio) with $0.05 \mathrm{M}$ carbonate/bicarbonate buffer, $\mathrm{pH} 9.6$, for $4 \mathrm{~h}$ at $4^{\circ} \mathrm{C}$ with continuous shak- 
ing. The suspensions were centrifuged at $4,000 \mathrm{~g}$ and the supernatants utilized for the assay (see below).

\section{Polyacrylamide gel electrophoresis and Western blotting}

Protein extracts $(50 \mu \mathrm{l})$ and commercial bovine insulin $(10 \mu \mathrm{g})$ were submitted to SDS-PAGE by the method of Laemmli (25). Electrophoresis was run for $4 \mathrm{~h}$ at $15 \mathrm{~mA}$. Gels were stained with $0.25 \%(\mathrm{w} / \mathrm{v})$ Coomassie brilliant blue $\mathrm{R}$ in methanol/acetic acid/water (5/1/4) and destained in the same solution. Western blotting (26) to nitrocellulose membranes was performed using a semidry device and a buffer consisting of $25 \mathrm{mM}$ Tris, $192 \mathrm{mM}$ glycine and $20 \%$ methanol. Transfer was done at $1 \mathrm{~mA} / \mathrm{cm}^{2}$ for $4 \mathrm{~h}$. After transfer and blocking with non-fat milk, proteins were identified using the guinea pig anti-insulin (human) antibody (Peninsula Laboratories) as primary antibody and an IgG peroxidase complex. A positive reaction was detected by chemiluminescence.

\section{Insulin detection}

The presence of insulin-like antigens in the bacteria, fungi and plant extracts studied was determined in an assay developed for 96-well plates (Nunc-Maxisorp). The control insulin solution (bovine insulin, $1 \mu \mathrm{g} /$ $100 \mu \mathrm{l})$ and the different extracts, all prepared in $0.05 \mathrm{M}$ carbonate/bicarbonate buffer, $\mathrm{pH} 9.6$, were pipetted into the wells of a plate (100 $\mu 1$ of each solution) and left to stand for $16 \mathrm{~h}$ at $4^{\circ} \mathrm{C}$. The solutions were then discarded and the wells were washed for $1 \mathrm{~h}$ (changing solutions every $10 \mathrm{~min}$ ) with $0.05 \%$ Tween 20 in $0.1 \mathrm{M}$ phosphate, $0.5 \mathrm{M} \mathrm{NaCl}, \mathrm{pH} 7.6$ (buffer A). After washing, $300 \mu$ l of a blocking buffer ( $1 \%$ gelatin, $0.05 \%$ Tween 20 in $0.01 \mathrm{M}$ phosphate buffer, $0.5 \mathrm{M} \mathrm{NaCl}, \mathrm{pH}$ 7.6) was added to the wells for $1 \mathrm{~h}$. The plates were again washed for $1 \mathrm{~h}$ as described above. After the washings, 50 $\mu 1$ of the anti-human insulin antibody solution (1:5000 dilution) prepared with blocking buffer was added to the wells and left to stand at room temperature for $45 \mathrm{~min}$. The plates were then washed with buffer A for 30 min, with changes every $5 \mathrm{~min}$, and incubated with $50 \mu \mathrm{l}$ of peroxidase-conjugated anti-IgG (1:2000) in blocking buffer at room temperature for $45 \mathrm{~min}$. The plates were then washed four times with buffer A for 5 min each time. The substrate for peroxidase (10 $\mathrm{mg}$ ortho-phenylenediamine in $25 \mathrm{ml}$ of 26 $\mathrm{mM}$ citrate $/ 52 \mathrm{mM}$ phosphate buffer, $\mathrm{pH}$ 5.0, with $10 \mu 1$ hydrogen peroxide) was then added and the plates were left to stand for 10 min in the dark at room temperature. The reaction was stopped by the addition of $50 \mu 1$ $3 \mathrm{~N}$ sulfuric acid and absorbance was read with an ELISA reader at $490 \mathrm{~nm}$ (27). A sample was considered positive when the reading at $490 \mathrm{~nm}$ was above that of the control (buffer without insulin).

\section{Results}

\section{Detection of insulin-like antigens in solution}

Table 1 shows a list of plants whose leaves or other aerial parts tested positive for insulin in the qualitative plate assay described above. The results suggest that insulin-like antigens were present in most of the leaves examined. The plants which tested positive belonged to a diversity of phyla like Bryophyta (mosses), Psilophyta (whisk ferns), Lycopodophyta (Selaginella sp), Sphenopsida (horsetails, Equisetum), gymnosperms (Coniferophyta, the conifers; Cycadophyta, the cycads; Ginkgophyta, ginkgos), and angiosperms (flowering plants including monocotyledons and dicotyledons). We also showed that the alga Gracilariopsis sp, a common red alga from estuarine habitats, the cyanobacterium Spirulina maxima, and fungi like Shiitake (Lentinus edodes) and the yeast Saccharomyces cerevisiae all contain insulin-like antigens (Table 1). 
Table 1. List of phyla (green plants, cyanobacterium, red alga, and fungi) and species which tested positive for insulinlike antigens with an antibody to human insulin.

\begin{tabular}{|c|c|c|c|}
\hline Phylum (kingdom) & Division & Species & Common name \\
\hline Eubacteria & Cyanobacteria & Spirulina maxima & Spirulin \\
\hline Fungi & $\begin{array}{l}\text { Ascomycota } \\
\text { Basidiomycota }\end{array}$ & $\begin{array}{l}\text { Saccharomyces cerevisiae } \\
\text { Lentinus edodes }\end{array}$ & $\begin{array}{l}\text { Yeast } \\
\text { Shiitake }\end{array}$ \\
\hline Protoctista & Rhodophyta (red algae) & Gracilariopsis sp & \\
\hline \multirow[t]{9}{*}{ Plantae } & Bryophyta (mosses) & $\begin{array}{l}\text { Frullania kunzei } \\
\text { Meteorium nigrescens } \\
\text { Bryum denupliun } \\
\text { Marchantia chenegada }\end{array}$ & $\begin{array}{l}? \\
? \\
? \\
?\end{array}$ \\
\hline & Psilophyta (whisk ferns) & Psilotum sp & \\
\hline & Lycopodophyta (club mosses) & Selaginella sp & Spike moss \\
\hline & Sphenopsida (horsetails) & Equisetum sp & \\
\hline & Gymnosperms-Coniferophyta (conifers) & $\begin{array}{l}\text { Pinus ponderosa } \\
\text { Cupressus sempervirens }\end{array}$ & $\begin{array}{l}\text { Poderosa pine } \\
\text { Cypress }\end{array}$ \\
\hline & Gymnosperms-Cycadophyta (cycads) & Cycas revoluta & Sago palm \\
\hline & Gymnosperms-Ginkgophyta (ginkgos) & Ginkgo biloba & Ginkgo \\
\hline & Anthophyta-Angiosperms-Monocotyledons & $\begin{array}{l}\text { Euterpe oleracea } \\
\text { Bactris gasipaes } \\
\text { Zea mays } \\
\text { Saccharum officinarum }\end{array}$ & $\begin{array}{l}\text { Açaí palm } \\
\text { Pupunha } \\
\text { Maize } \\
\text { Sugar cane }\end{array}$ \\
\hline & Anthophyta-Angiosperms-Dicotyledons & $\begin{array}{l}\text { Persea americana } \\
\text { Annona muricata } \\
\text { Hevea brasiliensis } \\
\text { Cissus cicyoides } \\
\text { Peumus boldus } \\
\text { Spinacia oleracea } \\
\text { Licania rigida } \\
\text { Coupeia canomensis } \\
\text { Tamarindus indicus } \\
\text { Bauhinia forficata } \\
\text { Canavalia ensiformis } \\
\text { Phaseolus vulgaris } \\
\text { Vigna unguiculata } \\
\text { Averrhoa carambola } \\
\text { Brassica oleracea capitata } \\
\text { Arabidopsis thaliana } \\
\text { Adamsonia digitata } \\
\text { Ocimum sp } \\
\text { Mentha arvensis } \\
\text { Ilex paraguariensis } \\
\text { Pimpinella anisum } \\
\text { Baccharis genistelloides } \\
\text { Lippia alba } \\
\text { Aspidosperma carapanauba } \\
\text { Sambucus sp } \\
\text { Matricaria chamomilla } \\
\text { Eucalyptus }\end{array}$ & $\begin{array}{l}\text { Avocado } \\
\text { Graviola } \\
\text { Ruber tree } \\
\text { Cipó-pucá } \\
\text { Boldo } \\
\text { Spinach } \\
\text { Oticica tree } \\
\text { Bajuru } \\
\text { Tamarind } \\
\text { Pata-de-vaca } \\
\text { Jack bean } \\
\text { Common bean } \\
\text { Cowpea } \\
\text { Carambola } \\
\text { Cabbage } \\
\text { Thale cress } \\
\text { Baoba } \\
\text { Basil } \\
\text { Mint } \\
\text { Mate } \\
\text { Anise } \\
\text { Carqueja } \\
\text { Erva cidreira } \\
\text { Carapanauba } \\
\text { Sabugueiro } \\
\text { Chamomille } \\
\text { Eucalyptus }\end{array}$ \\
\hline
\end{tabular}

Classification of green plants and other phyla as given by Raven et al. (28). 

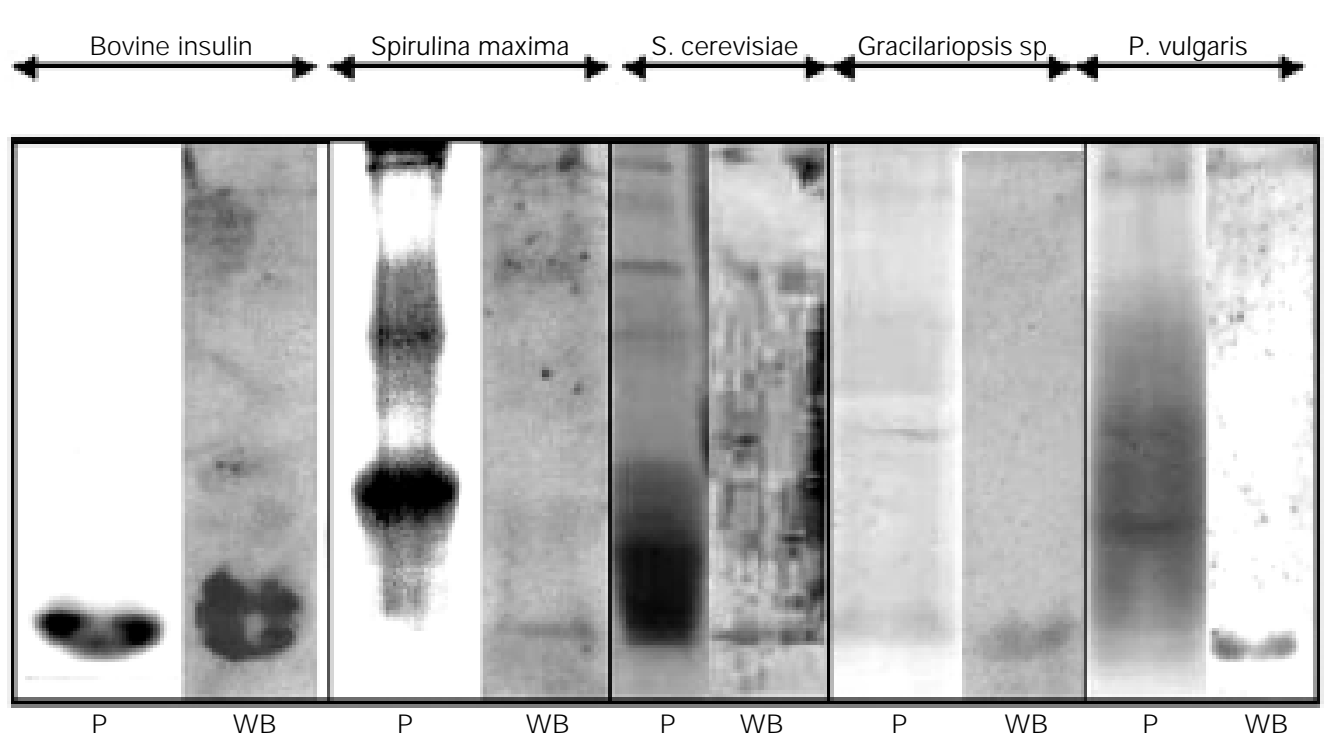

\section{Western blotting}

Some of the plant materials that tested positive for insulin-like antigens in the plate assay utilized and listed in Table 1 were further analyzed by Western blotting after SDS-PAGE using the same anti-human insulin antibody as for the plate assay. Some of the results obtained are presented in Figure 1. Extracts from $S$. maxima, $S$. cerevisiae, Gracilariopsis sp and Phaseolus vulgaris all showed bands that stained positive by Western blotting. In addition to a positive signal confirming the findings for the plate assay (above) the position of the bands suggests that the stained materials have the same molecular weight as bovine insulin.

\section{Discussion}

A considerable number of reports on the presence of insulin-like molecules in extracts from many different species ranging from unicellular prokaryotes and eukaryotes to multicellular invertebrates and vertebrates have been published. These molecules have always been detected by employing antibodies raised against vertebrate insulins and different chromatographic techniques. Many of these have proved to be functional in bio- logical insulin assays $(12,13,29,30)$.

The presence of insulin-like antigens in plants was previously reported by Collier et al. (8) in a study on the flowering plants spinach, rye and Lemna gibba. These investigators also showed that the isolated molecules behave like vertebrate (porcine) insulins in reversedphase HPLC, bind to insulin receptors on lymphocytes and stimulate glucose oxidation and lipogenesis in isolated rat adipocytes.

In addition, we recently reported that some leguminous plants (dicotyledons) contain insulin-like antigens. In fact these antigens isolated from seed coats, leaves and developing fruits were shown to be proteins with molecular weights similar to those of vertebrate insulins and to possess the same amino acid sequence as bovine insulin (31; Venâncio TM, Oliveira AEA, Machado OLT, Fernandes KVS and Xavier-Filho J, unpublished results).

We report here on the screening of several green plants, algae, fungi, and a cyanobacterium for the presence of insulin-like antigens (Table 1). Particularly interesting was the finding of insulin-like antigens in Arabidopsis thaliana, the model plant for genetic and biochemical studies (32,33). However, we could not find any sequences related to vertebrate insulins or plant insu-
Figure 1. SDS-polyacrylamide gel electrophoresis and Western blotting of extracts from leaves and cells of Phaseolus vulgaris, Gracilariopsis sp, Saccharomyces cerevisiae, Spirulina maxi$\mathrm{ma}$, and bovine insulin. Western blot was done using an anti-human insulin antibody and the reaction was visualized by chemiluminescence. $\mathrm{P}$, protein (Coomassie brilliant blue staining); WB, Westem blotting. 
lins like those from jack bean (Canavalia ensiformis) (31) and cowpea (Vigna unguiculata) (Venâncio TM, Oliveira AEA, Machado OLT, Fernandes KVS and XavierFilho J, unpublished results) in the published genome sequences of this plant (34). Extracts of $P$. vulgaris leaves, the $\operatorname{dicot} A$. thaliana and the legume $V$. unguiculata tested positive for insulin-like antigens in the plate assay (Table 1) and gave a positive reaction in Western blots (Figure 1).

A suggestion that algae may contain or depend on insulin for metabolic processes was previously made by Legros et al. (35) who showed the presence of insulin receptors in the plasma membrane of the unicellular green alga Acetabularia mediterranea. In the present study we show that extracts of the red alga Gracilariopsis sp tested positive for insulin-like antigens in the plate assay (Table 1) and presented a band at roughly the same position as bovine insulin in Western blots (Figure 1).

The presence of insulin in fungi would seem to be undisputed since a pseudogene for preproinsulin was cloned from Neurospora crassa (ascomycete) (36) and insulinlike proteins were purified from $S$. cerevisiae, also an ascomycete, by Best et al. in 1924 (37). More recently, insulin-like antigens were isolated from the fungus Aspergillus fumigatus, also an ascomycete (29). In the present study we detected insulin-like antigens in the edible fungus Shiitake (Lentinus edodes), a basidiomycete, and in $S$. cerevisiae. In yeast extracts we showed the presence of a band in Western blots at the same position as bovine insulin (Figure 1).

We also included in our study the cyanobacterium Spirulina maxima, widely cultivated for food and dietary supplements (38). It is worth noting here that the cyanobacteria are photosynthesizing organisms accepted to have given origin to the chloroplasts of green plants through endosymbiontic processes occurring millions of years ago. Extracts of $S$. maxima have tested positive for insulin-like antigens (Table 1) and a band was detected in Western blots after SDSPAGE (Figure 1).

The presence of insulin in extra-pancreatic tissues from vertebrates, invertebrates, microorganisms or plants is still denied by most researchers. The grounds for this are many, including the fact that the insulins found in non-pancreatic tissues would not be true insulins but rather what is called insulinlike or insulin-related molecules with similar albeit different structures which are not involved in metabolic processes (glucose metabolism). These molecules include the insulin-like growth factors from vertebrates, bombyxins from silkworm, molluscan insulin-like peptides, and others (14). In spite of the many reports on the effects of extracts from plant parts on the reduction of blood sugar levels of diabetic animals $(4,16,17)$, no function for insulin has been suggested by workers in the fields of glucose mobilization or transport (18-21). Nevertheless, it has been shown recently that insulin increases seed germination (22; Oliveira AEA and Xavier-Filho J, unpublished results), accelerates synthesis of ribosomal proteins in germinating maize embryos $(23,24)$, and increases the activity of glyoxysomal enzymes in maize (22).

Although the amino acid sequences for the great majority of the plant insulin-like molecules reported here are not known, it is tempting to speculate that the molecules isolated from $C$. ensiformis (31) and $V$. unguiculata (Venâncio TM, Oliveira AEA, Machado OLT, Fernandes KVS and Xavier-Filho J, unpublished results) are true insulins. Results from our laboratory as well as those reported by many previous investigators suggest that insulin is a molecule present in all organisms, from unicellular bacteria to multicellular vertebrates. The wide phylogenetic distribution of insulin would probably be easily accepted if its function as a component of a metabolic signaling pathway involved in glucose metabolism were confirmed. 


\section{References}

1. Banting FG \& Best CH (1922). The internal secretion of the pancreas. J ournal of Laboratory and Clinical Medicine, 7: 465480.

2. Collip J B (1923). Glucokinin. A new hormone present in plant tissue. Preliminary paper. J ournal of Biological Chemistry, 56 : 513-543.

3. Best CH (1924). Recent work on insulin. Endocrinology, 8: 617-629.

4. Gray AM \& Flatt PR (1997). Nature's own pharmacy: The diabetes perspective. Proceedings of the Nutrition Society, 56: 507517.

5. Khanna P, Nag TN, J ain SC \& Mohan S (1974). Extraction of insulin from a plant source. 3rd International Congress on Plant Tissue and Cell Cultures, J uly 21-26, Leicester, UK.

6. Khanna P, Nag TN, Chandrajaia S \& Mohan $S$ (1976). Process for isolation of insulin from plant source. Granted United States Patent, 3: 945-988.

7. Khanna P, J ain SC, Panagariya A \& Dixit VP (1981). Hypoglycemic activity of polypeptide-P from a plant source. J ournal of Natural Products, 44: 648-655.

8. Collier E, Watkinson A, Cleland CF \& Roth J (1987). Partial purification and characterization of an insulin-like material from spinach and Lemna gibba G3. J ournal of Biological Chemistry, 262: 6238-6247.

9. Baumann CA, Ribon V, Kanzaki M, Thurmond DC, Mora S, Shigematsu S, Bickel PE, Pessin J E \& Saltiel AR (2000). CAP defines a second signalling pathway required for insulin-stimulated glucose transport. Nature, 407: 202-207.

10. Brüning J C, Gautmam D, Burks DJ, Gillette J , Schubert M, Orban PC, Klein R, Krone W, Müller-Wieland D \& Kahn CR (2000). Role of brain insulin receptor in control of body weight and reproduction. Science, 289: 2122-2125.

11. Alper J (2000). New insights into type 2 diabetes. Science, 289: 37-39.

12. LeRoith D, Shiloach J, Heffron R, Rubinovitz C, Tanenbaum R \& Roth J (1985). Insulin-related material in microbes: similarities and differences from mammalian insulins. Canadian J ournal of Biochemistry and Cell Biology, 63: 839-849.

13. LeRoith $D$, Delahunty $G$, Wilson GL, Roberts J r CT, Shemer J, Hart C, Lesniak MA, Shiloach J \& Roth J (1986). Evolutionary aspects of the endocrine and nervous systems. Recent Progress in Hormone Research, 42: 549-587.
14. Chan SJ \& Steiner DJ (2000). Insulin through the ages: phylogeny of a growth promoting and metabolic regulatory hormone. American Zoologist, 40: 213-222.

15. Sower SA, Suzuki K \& Reed KL (2000). Perspective: Research activity of enteropancreatic and brain/central nervous system hormones across invertebrates and vertebrates. American Zoologist, 40: 165178.

16. Platel K \& Srinivasan K (1997). Plant foods in the management of diabetes mellitus: vegetables as potential hypoglycaemic agents. Nahrung, 41: 68-74.

17. Ernst E (1997). Plants with hypoglycemic activity in humans. Phytomedicine, 4: 7378.

18. Ward J M, Kühn C, Tegeder M \& Frommer WB (1998). Sucrose transport in higher plants. International Review of Cytology, 178: 41-71.

19. Wobus U \& Weber H (1999). Sugars as signal molecules in plant seed development. Biological Chemistry, 380: 937-944.

20. Williams LE, Lemoine R \& Sauer N (2000). Sugar transporters in higher plants - a diversity of roles and complex regulation. Trends in Plant Sciences, 5: 283-290.

21. Lemoine R (2000). Sucrose transporters in plants: update on function and structure. Biochimica et Biophysica Acta, 1465: 246-262.

22. Goodman DBP \& Davis WL (1992). Insulin accelerates the post germinative development of several fat storing seeds. Biochemical and Biophysical Research Communications, 190: 440-446.

23. Sánchez de J iménez E, Beltrán-Penã E \& Ortíz-López A (1999). Insulin-stimulated ribosomal protein synthesis in maize embryonic axis during germination. Physiologia Plantarum, 105: 148-154.

24. Dinkova TD, Aguilar $R$ \& Sánchez de J iménez E (2000). Expression of maize eukaryotic initiation factor (elF) iso4E is regulated at the translational level. Biochemical J ournal, 351: 825-831.

25. Laemmli UK (1970). Cleavage of structural proteins during the assembly of the head of bacteriophage T4. Nature, 227: 680-685.

26. Towbin H, Staehelin NT \& Gordon J (1979). Electrophoretic transfer of proteins from polyacrylamide gels to nitrocellulose sheets; procedures and some applications. Proceedings of the National Academy of Sciences, USA, 176: 43504354.
27. Gebara VCB, Petricevich VL, Raw I \& Da Silva WD (1995). Effect of saponin from Quillaja saponaria (Molina) on antibody, tumour necrosis factor and interferon- $\gamma$ production. Biotechnology and Applied Biochemistry, 22: 31-37.

28. Raven PH, Evert RF \& Eichhorn SE (1992). Biology of Plants. 5th edn. Worth Publishers, New York, NY, USA.

29. LeRoith D, Shiloach J , Roth J \& Lesniak MA (1980). Evolutionary origins of vertebrate hormones: Substances similar to mammalian insulins are native to unicellular eukaryotes. Proceedings of the National Academy of Sciences, USA, 77: 6184-6188.

30. LeRoith D, Shiloach J , Roth J \& Lesniak MA (1981). Insulin or a closely related molecule is native to Escherichia coli. J ournal of Biological Chemistry, 256: 6533-6536.

31. Oliveira AEA, Machado OLT, Gomes VM, Xavier Neto J, Pereira AC, Vieira J GH, Fernandes KVS \& Xavier-Filho J (1999). J ack bean seed coat contains a protein with complete sequence homology to bovine insulin. Protein and Peptide Letters, 6: 15-21.

32. Negrutiu I, Beeftink F \& J acobs M (1975). Arabidopsis thaliana as a model system in somatic cell genetics. 1 . Cell and tissue culture. Plant Science Letters, 5: 293-304.

33. Meinke DW, Cherry J, Dean C, Rounsley SD \& Koornneef M (1998). Arabidopsis thaliana: A model plant for genome analysis. Science, 282: 662-682.

34. The Arabidopsis Information Resource (2001). Available at: http://www. arabidopsis.org. Accessed November 20, 2001.

35. Legros $F$, Uytdenhoef $P$, Dumont I, Hanson B, J eanmart J, Massant B \& Conard V (1975). Specific binding of insulin to the unicellular alga Acetabularia mediterranea. Protoplasma, 86: 119-134.

36. Muthukumar G \& Lenard J (1991). A preproinsulin-like pseudogene from Neurospora crassa. Molecular and Cellular Endocrinology, 82: 275-283.

37. Best CH, Smith RG \& Scott DA (1924). An insulin-like material in various tissues of the normal and diabetic animal. American J ournal of Physiology, 68: 161-182.

38. Kay RA (1991). Microalgae as food and supplement. Critical Reviews in Food Science and Nutrition, 30: 555-573. 